\title{
Development of a Device to Pulping Fruits of Bocaiuva (Acrocomia aculeate sp.): Intended for the Communities that Practice Sustainable Agriculture or Strativism
}

\author{
Carlos Alberto Machado Chuba ${ }^{1,2}$, Ramon Eduardo Pereira Silva ${ }^{2}$, Andrea Cristina dos Santos ${ }^{3}$ \\ \& Eliana Janet Sanjinez-Argandoña ${ }^{2}$ \\ ${ }^{1}$ Program in Biotechnology and Biodiversity, Rede Pró Centro, Oeste, Brazil \\ ${ }^{2}$ Faculty of Engineering, Federal University of Grande Dourados, Dourados, MS, Brazil \\ ${ }^{3}$ Faculty of Technology, University of Brasília, Brasília, DF, Brazil \\ Correspondence: Carlos Alberto Machado Chuba, Dourados HWY-Itahum, km 12, 79.804-970, Dourados, State \\ of Mato Grosso do Sul, Brazil. Tel: 55-673-410-2160/55-679-8145-2151. E-mail: carloschuba@gmail.com; \\ carloschuba@ufgd.edu.br
}

Received: May 26, 2018

doi:10.5539/jas.v11n2p397
Accepted: November 17, 2018 Online Published: January 15, 2019

URL: https://doi.org/10.5539/jas.v11n2p397

\begin{abstract}
Bocaiuva (Acrocomia aculeata) fruit pulp has high potential for food, pharmaceutical and cosmetic applications and in the biofuel industry, however, the main hindrance for these applications is the availability of pulp in sufficient quantity. The pulp of this fruit is usually supplied by rural communities where the processors use manual pulping, which is not only time-consuming but yields product of low quality. Therefore, the objective of this work was to design, fabricate and evaluate the efficiency of an experimental bench device for pulping bocaiuva fruits. The bench device was designed to be compact and easy to operate, consisting of three units (processing, secondary, and peripheral) with intermittent operation and pulping performed by shearing. The performance evaluation of the machine was carried out with fruit dehydrated at $70^{\circ} \mathrm{C}$ and different times of dehydration $(6,12$ and 24 hours). The pulp weight was evaluated every 15 seconds during the pulping process period ( 150 seconds). The highest pulping efficiency $(96 \%)$ was obtained with fruits that were dehydrated for 24 hours, with a 120 -second pulping, which resulted in a production rate of $5.5 \mathrm{~kg} \mathrm{~h}^{-1}$ This high efficiency makes this mechanized prototype effective for pulping bocaiuva fruits and, thus, it can replace manual pulping, especially in rural communities involved with the bocaiuva production chain.
\end{abstract}

Keywords: agroecology, product development, fruits of the Cerrado, macaúba, mechanization, prototype

\section{Introduction}

Native fruits of brazilian biome entitled Cerrado are a source of income for many families, contribute to biodiversity conservation and are related to cultural richness. The mechanization solutions available in the market are not fully developed and still present high costs. However, specific devices for fruit processing, related to a sustainable extraction, for small farmer cooperatives are scarce. Bocaiuva (Acrocomia aculeata) is one of the most abundant native fruits of the Cerrado biome, especially in the State of Mato Grosso do Sul (MS), Brazil. This fruit has spherical shape and consists of epicarp (20\%), mesocarp (42\%), endocarp (31\%) and seed (7\%). The edible, sweet-tasting pulp is oleaginous, fibrous, mucilaginous, and strongly adhered to the rigid and dark endocarp, hindering the pulping process (Farias, 2010).

Bocaiuva pulp has high nutritional value due to its high contents of lipids, carbohydrates, proteins, carotenoids, and fibers, which are important for human health (Ciconini et al., 2013; Coimbra \& Jorge, 2012; Ramos et al., 2008). Scientific studies showed the use of this pulp and seed to elaborate edible products, such as food bars (Munhoz et al., 2014) and sweet and salt biscuits, which are considered a source of fiber and vitamin A (Kopper, Saravia, Ribani, \& Lorenzi, 2009). This fruit can also be used to prepare ice creams, jellies, and cakes (Aristone \& Leme, 2006). Bocaiuva is currently marketed as flour, produced by rural communities through artisanal procedures. Bocaiuva also has industrial potential for pharmaceuticals (Oliveira, Clemente, \& da Costa, 2014; Coimbra \& Jorge, 2012) and cosmetics (Bortolotto, Amorozo, Guarim Neto, Oldeland, \& Damasceno-Junior, 2015; Coimbra \& Jorge, 2012), and for biofuel production, due to its fatty acid composition (Nascimento, Soares, Stragevitch, \& 
Danielski, 2016; Cavalcanti-Oliveira et al., 2015; Nunes, Favaro, Galvani, \& Miranda, 2015; Machado et al., 2015; Silva \& Andrade, 2013).

Although no official production data of bocaiuva fruits is found in Brazil, several communities exploit commercially these fruits. According to Pennachio (2017), Acrocomia sp. is found in approximately $12 \mathrm{mi}$ hectares of the Cerrado biome. It is estimated that commercial plantations of Acrocomia sp. produce approximately $25 \mathrm{Mg} \mathrm{ha}^{-1}$ ano $^{-1}$ of fruits, and 4 to $6 \mathrm{Mg}$ of oil are extracted from their pulp (Azevedo Junior, Faria, Santana, Reis, \& Almeida, 2018; Cruz, Ferreira, \& Rodrigues, 2017).

The major impediment for these applications is the non-availability of bocaiuva pulp that presents enough quantity and quality, due to the slow process of manual pulping. Thus, the handcrafted pulp production shall be progressively replaced by mechanized methods to increase the productivity and improve work conditions.

The technology and its access were found to be major variables that shape development proposals and influence the resilience of family's (Machado \& Rovere, 2017). Researches aiming to develop practical solutions for mechanization for resources from extractive reserves or improving the family farming are still incipient (Kloster \& Cunha, 2014). However, the acquirement of mechanized devices leads to the consolidation of the local rural activity and contributes to the decrement of social problems, and reduction of rural exodus (Arruda, Matos, Machado, \& Arruda, 2015). Therefore, the unavailability of off-the-shelf compact devices promotes the opportunity to their development, looking for practicality and uniformity of products obtained from resources from the biodiversity that are available in the Cerrado.

Thus, the use of experimental bench devices under actual operating conditions assists in the searching for compact prototypes that are intended to study specific characteristics of fruit pulps and improve the processing performance (Leite, 2012). Therefore, the development of experimental rigs has been used for assessments on productive systems used by rural communities. For example: Jarimopas and Ruttanadat (2007), developed a prototype for trimming green coconut (Cocos nucifera) shells, and Raji and Olofin, (2011), designed and fabricated a device to extract proteins from pumpkin (Telfairia occidentals) leaves for human consumption in African communities. In addition, Owolarafe, Adetan, Olatunde, Ajayi, and Okoh (2013), developed and evaluated a process to peel carob (Parkia biglobosa); Obayopo, Taiwo, Owolarafe, and Adio (2014), designed a compact device to slice banana (Musa paradisiaca L.); and Math, Ramesh, Nagender, and Satyanarayana (2016), designed, fabricated, and evaluated a bench device to extract urucum (Bixa orellana $\mathrm{L}$.) pulp.

The use of shear extraction increases the efficiency of the process and preserves the nutritional characteristics of the fruits. It simulates the physical conditions of the pulp traditionally extracted and favors the homogeneity of the product.

Mechanical extraction of pulp increases the efficiency of this process and favors the product standardization. A device fabricated by researchers from the Federal University of Mato Grosso do Sul and Embrapa Pantanal that assists in native fruit processing is used in extractive agriculture in Miranda MS and Aquidauana MS.

The method of managing technology or product development can be used as a first step in the development of a prototype to facilitate and make feasible to fabricate experimental bench devices. The maturity level of the development of technologies and products can be assessed by this method, which was developed by NASA and called Technology Readiness Levels (TRL). It consists of classifying the development maturity into nine levels, from the creation of ideas to the monitoring of the product application.

The product application possibilities are assessed in the first level (TRL1). The concept or technological application is formulated, culminating with the invention project in the second level (TRL2). Analytical and experimental approaches are investigated and developed, and the concept is physically produced in the third level (TRL3). The bench device is validated in laboratory, resulting in the assembly of the device in the fourth level (TRL4).

The unavailability of compact devices opens perspectives to develop experimental bench devices, searching for practicality and standardization of products. Thus, this work intended to develop a technology specifically for rural communities, which need devices for pulp extraction of native fruits, help to increase the income of these communities and preserve the bocaiuva native palm.

In this context, the objective of this work was to design, fabricate and evaluate the efficiency of an experimental bench device for pulping bocaiuva fruits. 


\section{Material and Methods}

\subsection{Material}

The internal part of the bench device was fabricated with stainless steel sheets $(304 \mathrm{~L})$, as recommended by the Resolution 20 of March 22, 2007, of the Brazilian National Sanitary Surveillance Agency [ANVISA] (Brasil, 2007) for use in food processing machinery. Carbon steel was used on the external part. Ripe fruits of Acrocomia aculeata (Plant deposited in the DDMS Herbarium of the Federal University of Grande Dourados as No. 4783) were collected in the cities of Dourados $\left(22^{\circ} 19^{\prime} 83^{\prime \prime} \mathrm{S}, 54^{\circ} 82^{\prime} 26^{\prime \prime} \mathrm{W}\right.$, and $430 \mathrm{~m}$ of altitude) and Ponta Porã $\left(22^{\circ} 45^{\prime} 40^{\prime \prime} \mathrm{S}, 55^{\circ} 38^{\prime} 50^{\prime \prime} \mathrm{W}\right.$, and $572 \mathrm{~m}$ of altitude) in the state of Mato Grosso do Sul, Brazil, in the 2014 and 2015 crop seasons, selected, sanitized, and stored at $-18^{\circ} \mathrm{C}$.

\subsection{Methods}

\subsubsection{TRL Method}

The requirements of the project were identified through the TRL (Technology Readiness Levels) method of management and development (Mankins, 2009). The difficulty of manual pulping and advantages of mechanized pulping were identified, and the fabrication of the experimental bench device was proposed (TRL1). The initial requirements for designing the device were easy operation, low power consumption, compaction, high pulping process efficiency, high product quality, and low cost.

The pulp extraction by the combined effect of centrifugal force and shear of the fruits by the pulping cylinder wall was the concept of the bench device (TRL2). The results of the TRL1 and TRL2 led to the design and fabrication of the units that compose the bench device (TRL3) and its validation for operation (TRL4).

\subsubsection{The Bocaiuva Pulping Machine}

The bench device was fabricated in three units (processing, secondary, and peripheral). The different components of each unit are described in Table 1 . The external dimensions of the device were $850 \mathrm{~mm}$ long, $280 \mathrm{~mm}$ wide, 500 $\mathrm{mm}$ high, with a total weight of $25 \mathrm{~kg}$. The 12 components of the experimental bench device are showed in Figure 1.

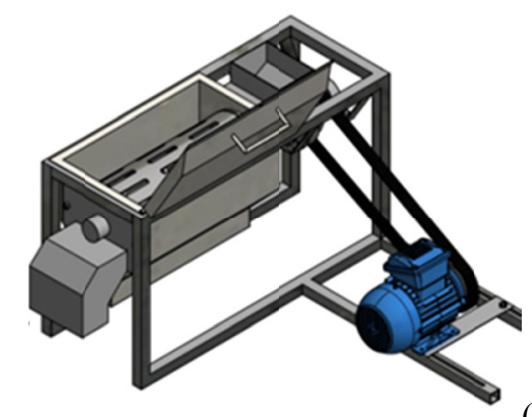

(a)

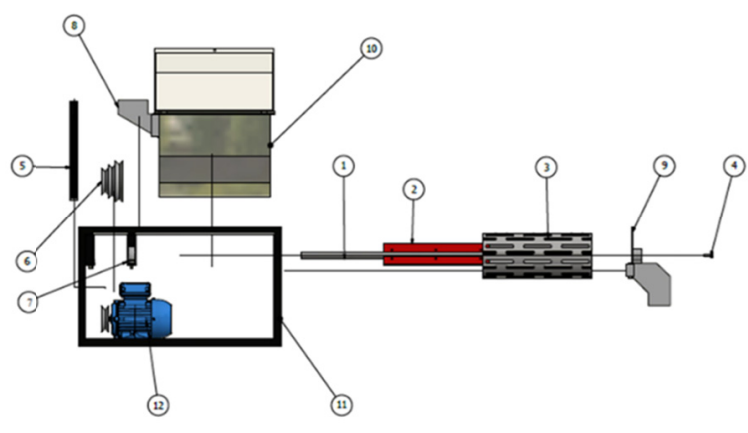

(b)

Figure 1. Projection of the experimental bench device built for pulping bocaiuva fruits and details of the projected components. 1. Shaft; 2. Vanes; 3. Cylinder; 4. Oblong holes; 5. Belt; 6. Pulley; 7. Bearing housing; 8. Input compartment; 9. Output compartment; 10. Carcass; 11. Chassis; 12. Motor 
Table 1. Datasheet of the units with description of the components of the experimental bench device for pulping bocaiuva fruits

\begin{tabular}{|c|c|c|c|c|c|c|}
\hline & Item & Components & Description & Specifications & Measure & Unit \\
\hline \multirow{9}{*}{ 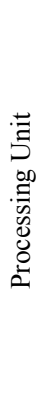 } & 1 & Shaft & 304L stainless steel billet & Diameter & 25.2 & $\mathrm{~mm}$ \\
\hline & 2 & Vanes & 304L stainless sheet & Thickness & 4 & $\mathrm{~mm}$ \\
\hline & 3 & Cylinder & 304L stainless steel sheet & Length & 400 & $\mathrm{~mm}$ \\
\hline & & & with oblong holes & Diameter & 150 & \\
\hline & & & & Thickness & 35 & \\
\hline & 4 & Oblong holes & Holes on the cylinder. & Area & 690 & $\mathrm{~mm}^{2}$ \\
\hline & & & & Amount & 72 & holes \\
\hline & & & & Length & 90 & $\mathrm{~mm}$ \\
\hline & & & & Width & 10 & \\
\hline \multirow{5}{*}{ 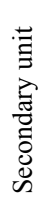 } & 5 & Belt & Classic V-Belt & A41-5114 (DIN 2215/ISO 4184) & 1 & piece \\
\hline & 6 & Pulley & 3 groove aluminum pulley & $65-90-115$ & 1 & piece \\
\hline & 7 & Bearing Housing & Cast iron and bearing assembly & Type P 205-UCP & 25.2 & $\mathrm{~mm}$ \\
\hline & 8 & Input Compartment & 304L stainless steel sheet & Thickness & 3 & $\mathrm{~mm}$ \\
\hline & 9 & Output Compartment & & & & \\
\hline \multirow{7}{*}{ 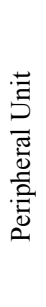 } & 10 & Carcass & 304L stainless steel sheet & Thickness & 2 & $\mathrm{~mm}$ \\
\hline & 11 & Chassis & External carbon steel cage, built in & Length & 760 & $\mathrm{~mm}$ \\
\hline & & & rectangular section profiles & Width & 280 & \\
\hline & & & & Height & 430 & \\
\hline & 12 & Motor & Mark Kohlbach $^{\circledR}$ & Power & 2.3 & $\mathrm{~kW}$ \\
\hline & & & & Rotation & 1700 & $\mathrm{rpm}$ \\
\hline & & & & Three Phase & 220 & $\mathrm{~V}$ \\
\hline
\end{tabular}

\section{(A) Processing Unit}

The processing unit of the experimental bench device consisted of shaft, vanes, and cylinder. The shaft diameter (Figure 1) was determined using torque and properties of the 304L stainless steel. Torque was calculated using the specifications of the electric motor power rating of $2.3 \mathrm{~kW}$ and speed of $1700 \mathrm{rpm}$ using Equation 1 (Melconian, 2012),

$$
\mathrm{M}_{\mathrm{t}}=30 \mathrm{P} / \pi \mathrm{n}
$$

where, $M_{t}$ is the torque (Nm), $P$ is the motor power (W) and $n$ is the rotation (rpm).

The resulting force $(\mathrm{Fr})$ transferred from the motor to the driven pulley was calculated using Equation 2 (Melconian, 2012),

$$
\mathrm{F}_{\mathrm{r}}=\left(\mathrm{F}_{1}^{2}+\mathrm{F}_{2}^{2}+2|\cos \propto|\right)^{1 / 2}
$$

where, $F_{l}$ is the driving force, $F_{2}$ is the resistance force $(\mathrm{N})$ and $\alpha$ is the arc (degrees) of the belt in contact with the pulley.

The forces on the vanes were calculated using Equation 3 (Melconian, 2012),

$$
\mathrm{F}_{\mathrm{p} 1}+\mathrm{F}_{\mathrm{p} 2}=\mathrm{M}_{\mathrm{t}} / \mathrm{r}
$$

where, $F_{p 1}$ and $F_{p 2}$ are the applied forces $(\mathrm{N}), M_{t}$ is the maximum torque $(\mathrm{Nm})$ and $r$ is the arm of the vanes (mm). The free-body diagrams, shear force, and flexion momentum were simulated using FTOOL application (Martha, 2002). The diameter (d) of the solid shaft was calculated using Equation 4 (Bhandari, 2010),

$$
\mathrm{d} \geq\left\{\left(16 / \pi \cdot \mathrm{S}_{\mathrm{c}}\right) \cdot\left[\left(\mathrm{K}_{\mathrm{b}} \cdot \mathrm{M}_{\mathrm{b}}\right)^{2}+\left(\mathrm{K}_{\mathrm{t}} \cdot \mathrm{M}_{\mathrm{t}}\right)^{2}\right]^{1 / 2}\right\}^{1 / 3} \cdot 10^{3}
$$

where, $M_{b}$ is the maximum flexion momentum $(\mathrm{Nm}), M_{t}$ is the torsional momentum $(\mathrm{Nm}), K_{b}$ is the flexion fatigue factor, $K_{t}$ is the torsional fatigue factor (Bhandari, 2010) and $S_{c}$ is the shear tension $\left(\mathrm{N} \mathrm{m}^{2}\right)$.

The shear tension $\left(S_{c}\right)$ on the shaft was calculated using the relation $\left(S_{c} \cong 0.6 \cdot S_{e}\right)$ proposed by (Garcia, Spim, \& Santos, 2012), wherein $S_{e}$ is the drain tension, set to $207 \times 10^{6} \mathrm{Nm}^{-2}$ for the $304 \mathrm{~L}$ stainless steel (Askeland \& Wright, 
2014). The shaft diameter was calculated considering the torque of $12.4 \mathrm{Nm}$ (Equation 1 ) of the $2.3 \mathrm{~kW}$ motor, whose resulting force applied to the driven pulley was $1042 \mathrm{~N}$ (Equation 2), and the force on each vane (Fp1 and Fp2) was $83 \mathrm{~N}$ (Equation 3).

The reaction forces of the three bear ing housings were calculated based on the force diagram (Figure 2), determining the maximum flexion momentum of $-31 \mathrm{Nm}$ (Figure 2c), used to calculate the minimum shaft diameter, which was $12.5 \mathrm{~mm}$ (Equation 4). However, considering the mucilaginous characteristics of the fruits, a safety factor of 2.17 was applied for the solid shafts (Melconian, 2012), which was fabricated with $25.4 \mathrm{~mm}$.

a)

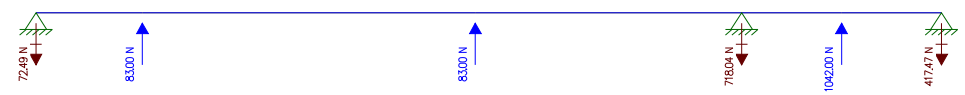

b)

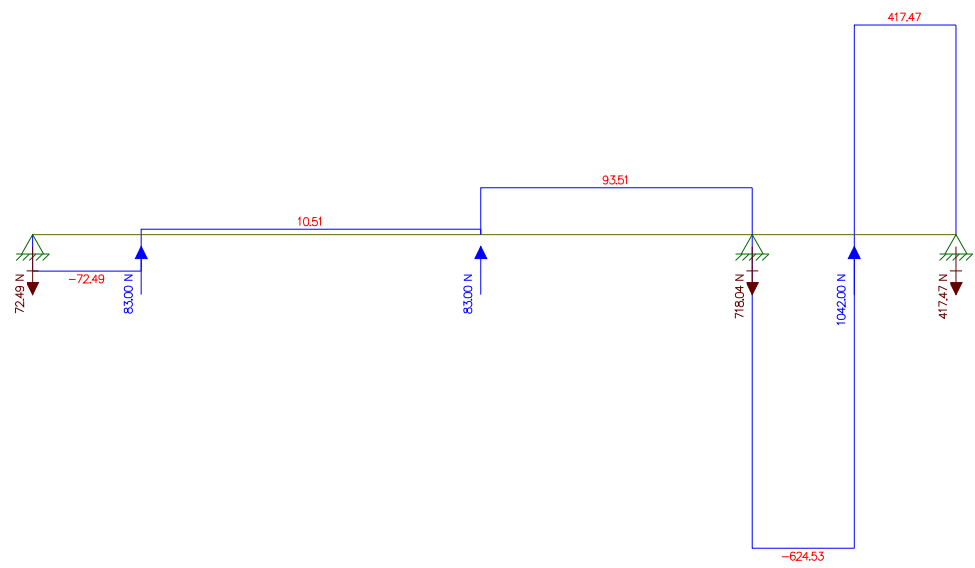

c)

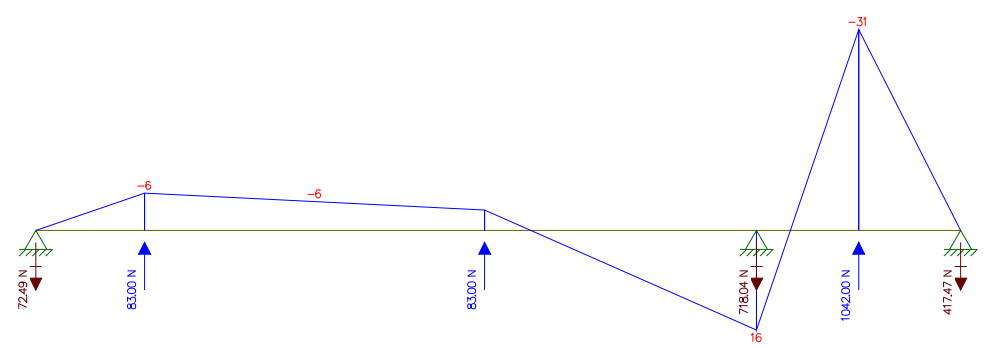

Figure 2. Force diagrams. a) Free-body diagram (N). b) Shear tension (N). c) Flexion momentum (Nm)

Two rectangular adjustable vanes (Table 1) were attached to the shaft and rotate inside the cylinder. The cylinder was made of 304L stainless steel sheets, perforated with oblong holes of $10 \mathrm{~mm}$ of width to facilitate removal of the pulp and be smaller than the average diameter of the endocarp. The rounded corners of the holes were chosen for preventing accumulation of pulp in the holes, besides having a larger surface cut similar to that of knives (Figure 3a). 


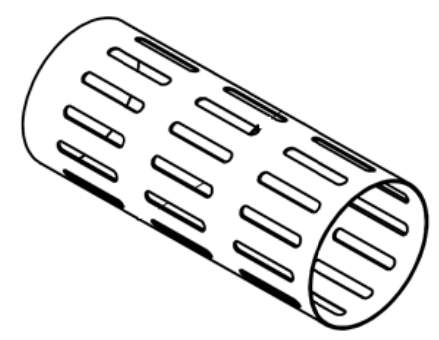

(a)
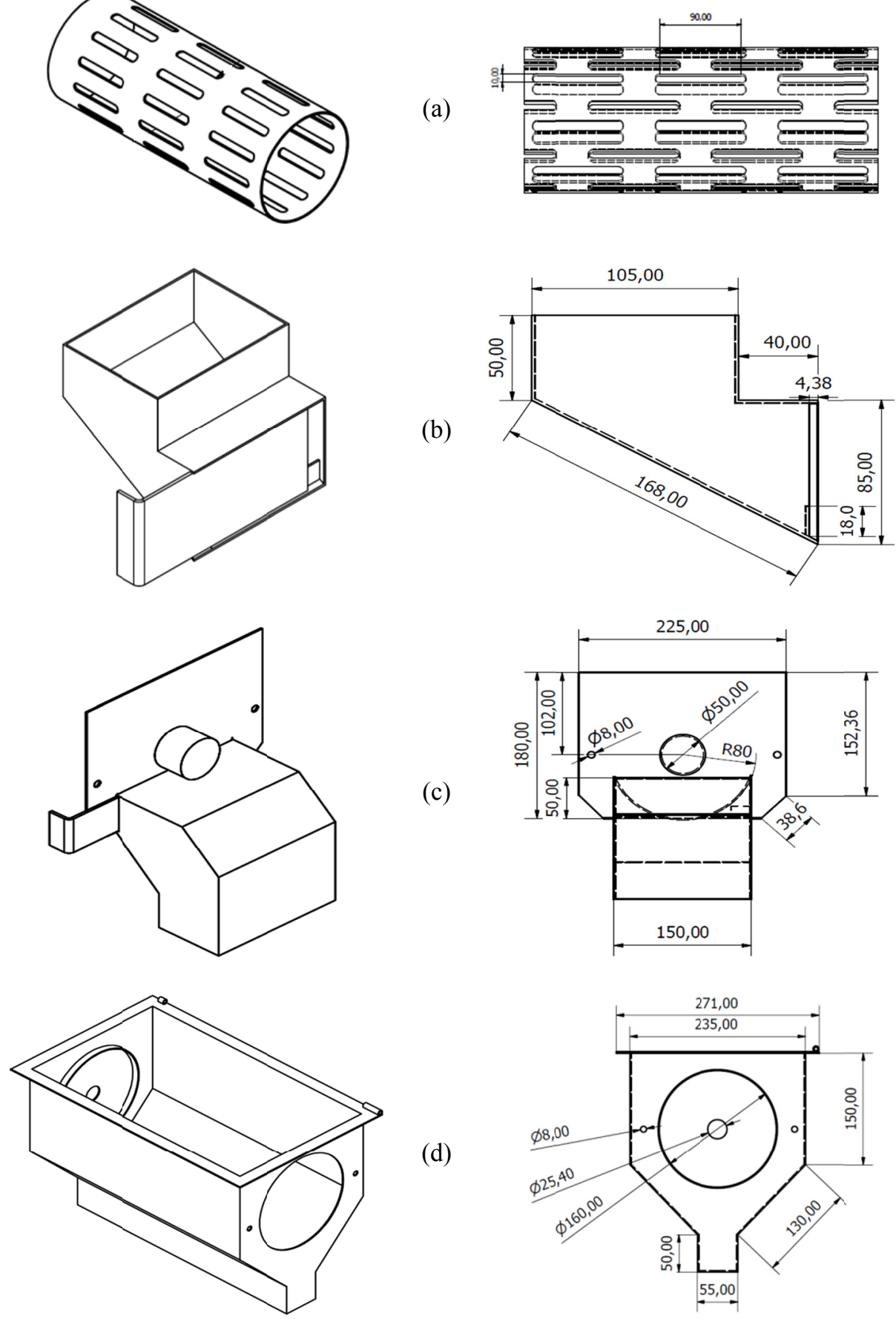

Figure 3. Perspectives and orthographic views (mm). (a) Cylinder with oblong holes; (b) Input compartment; (c) Output compartment; (d) Carcass

The cylinder was attached to the inside of the device carcass and fixed with screws to the output compartment. The shaft and vanes rotate freely inside the cylinder to promote friction with the fruits and removal of the pulp through the oblong holes (Figure 3a).

(B) Secondary Unit

The secondary unit consisted of input compartment, belt, pulleys, bearing housings, and output compartment. This unit drives the rotational movement of the shaft coupled to the driven power source by a classic V-belt with a motor pulley $(65 \mathrm{~mm})$ and a driven pulley $(105 \mathrm{~mm})$ fixed at the end of the shaft between the two bearing housings attached to the chassis of the bench device (Figure 1). 
The input compartment (Figure 3b), where the fruits are placed to feed the cylinder, was fixed to the upper part of the carcass. The output compartment (Figure 3c) was installed at the opposite end of the input compartment and had the tegument discharge function. Both compartments had doors to keep the system closed during pulping.

\section{(C) Peripheral Unit}

The peripheral unit consisted of carcass, chassis, and motor. The carcass formed the external part of the bench device (Figure 3d) and was designed to fix the cylinder and the input and output compartments. Inside this carcass occurs the pulping. A door was installed to facilitate cleaning in the upper part of this carcass.

The units of the bench device were coupled to a chassis (Figure 1) that assisted in the fixation of the motor, bearing housings and carcass, and has the function of aligning the shaft and vanes with the cylinder, granting stability to the prototype operation.

\subsubsection{Pulping Machine Operation}

The experimental bench device was built to operate in an intermittent process condition. The principle of operation consists of feeding the fruits into the system, turning on of the motor, removing the pulped product, and disposing the endocarp. The experimental procedure was performed as follows:

Whole fruits $(500 \mathrm{~g})$ were peeled, dehydrated, and introduced into the bench device cylinder through the input compartment (Figure 1). The input and output compartment doors were closed to prevent spill of the fruits when turning on the system that rotated the shaft and the vanes inside the cylinder.

The shaft rotated at $1051 \mathrm{rpm}$ for 150 seconds, shearing the fruits into the perforated wall of the cylinder, separating the pulp from the endocarp. During this process, the pulp was poured through the cylinder holes into a tray introduced underneath the carcass. Then, the output compartment was manually opened, the endocarps were discarded and the operation was resumed.

\subsubsection{Pulping Machine Validation}

Whole fruits were thawed at room temperature, peeled, weighed, and dehydrated at $70{ }^{\circ} \mathrm{C}$ in an oven that was fabricated according to Moreira Junior (2013), using three different times-6 $\mathrm{h}$ in treatment 1 (T1), $12 \mathrm{~h}$ in treatment 2 (T2), and $24 \mathrm{~h}$ in treatment 3 (T3)-for the experimental trials. The pulping process was performed in batches of $500 \mathrm{~g}$ of fruits. The pulp weight was evaluated every 15 seconds during the pulping process period (150 seconds).

The efficiency (EF) of the experimental bench device in extracting the bocaiuva pulp was calculated using Equation 5,

$$
\mathrm{EF}=\mathrm{PEB} /(\mathrm{PEB}+\mathrm{PNE}) \times 100
$$

where, $P E B$ is the total pulp extracted mechanically in the bench device and $P N E$ is the pulp that was not extracted and remained adhered to the endocarp after pulping.

\section{Results and Discussion}

\subsection{Result of Performance Evaluation of the Machine}

The pulping efficiency of the bench device was evaluated to establish the optimal process conditions. The pulp percentage extracted from the dehydrated bocaiuva fruits as a function of time in the device is shown in Figure 4. The highest amount of pulp extracted was observed in $\mathrm{T} 3$ and the lowest in $\mathrm{T} 1$, but the results of $\mathrm{T} 1$ and $\mathrm{T} 2$ were similar in the final pulp intervals. 


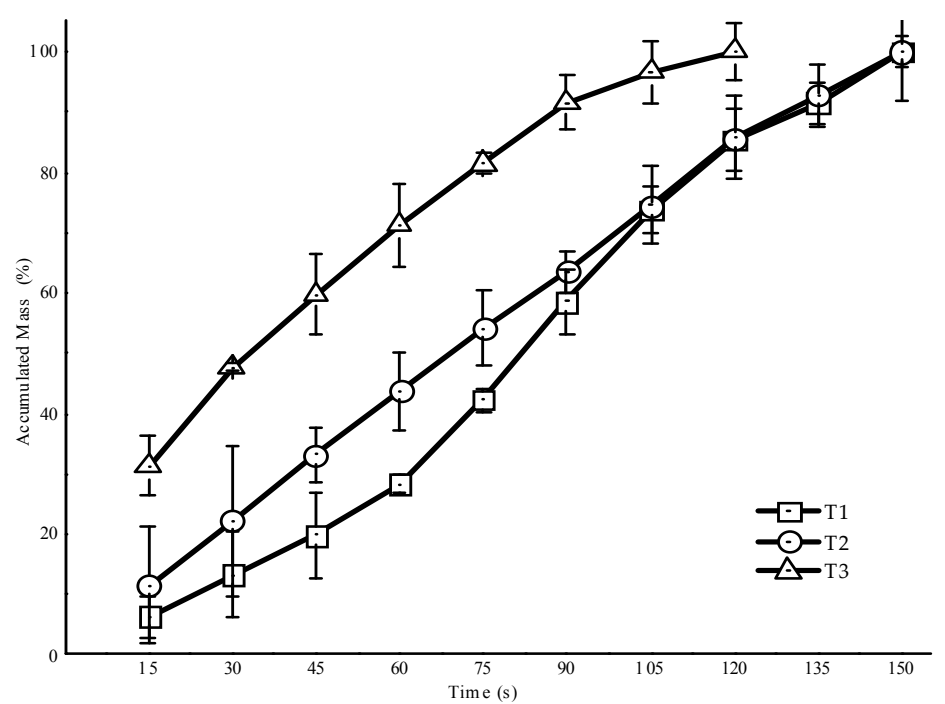

Figure 4. Percentage of mass accumulated during pulping of dehydrated bocaiuva fruits at $70^{\circ} \mathrm{C}$ for 6 (T1), 12 (T2) and 24 (T3) hours

The highest efficiency $\left(\mathrm{EF}_{120 \mathrm{~s}}\right)$ was found in $\mathrm{T} 3(96.0 \%)$, which had greater amount of pulp extracted in a shorter time (120 seconds). This result was statistically different from the other treatments $(\mathrm{p}<0.05)$. In the same time interval (120 seconds), $\mathrm{T} 1$ and $\mathrm{T} 2$ had extraction efficiency $\left(\mathrm{EF}_{120 \mathrm{~s}}\right)$ of $62.5 \%$ and $70.9 \%$, respectively (Table 2), with no significant difference $(\mathrm{p} \geq 0.05)$. However, in the extraction time of 150 seconds, the efficiency $\left(\mathrm{EF}_{150 \mathrm{~s}}\right)$ of T1 increased to $81.9 \%$ and T2 to $93.4 \%$, which were close to the result of T3 $(96.0 \%)$.

Table 2. Efficiency of the experimental bench device in the pulp extraction of dehydrated bocaiuva fruits (T1, T2 and T3)

\begin{tabular}{llllllll}
\hline Treatment & $\mathrm{TS}(\mathrm{h})$ & $\mathrm{PEB}_{120 \mathrm{~s}}(\mathrm{~g})$ & $\mathrm{PNE}_{120 \mathrm{~s}}(\mathrm{~g})$ & $\mathrm{EF}_{120 \mathrm{~s}}(\%)$ & $\mathrm{PEB}_{150 \mathrm{~s}}(\mathrm{~g})$ & $\mathrm{PNE}_{150 \mathrm{~s}}(\mathrm{~g})$ & $\mathrm{EF}_{150 \mathrm{~s}}(\%)$ \\
\hline $\mathrm{T} 1$ & 6 & $177.3 \pm 12^{\mathrm{a}}$ & $106.6 \pm 9^{\mathrm{a}}$ & $62.5^{\mathrm{a}}$ & $207.6 \pm 4^{\mathrm{a}}$ & $46.0 \pm 3^{\mathrm{a}}$ & $81.9^{\mathrm{a}}$ \\
$\mathrm{T} 2$ & 12 & $187.8 \pm 9^{\mathrm{a}}$ & $77.1 \pm 9^{\mathrm{a}}$ & $70.9^{\mathrm{a}}$ & $218.7 \pm 11^{\mathrm{ab}}$ & $15.3 \pm 3^{\mathrm{b}}$ & $93.4^{\mathrm{b}}$ \\
$\mathrm{T} 3$ & 24 & $228.7 \pm 2^{\mathrm{b}}$ & $9.7 \pm 2^{\mathrm{b}}$ & $96.0^{\mathrm{b}}$ & $228.7 \pm 2^{\mathrm{b}}$ & $9.7 \pm 2^{\mathrm{b}}$ & $96.0^{\mathrm{b}}$ \\
\hline
\end{tabular}

Note. T1: Dehydration for 6 hours; T2: Dehydration for 12 hours; T3: Dehydrated for 24 hours; TS: Time of dehydration in oven; PEB: Pulp extracted in the bench device; PNE: Pulp not extracted; EF: Efficiency; Same letters in the same column did not differ sig nificantly $(\mathrm{p}>0.05)$.

The moisture contents of the dehydrated fruits were $38.3 \%$ (T1), 19.0\% (T2) and 9.3\% (T3). The decreased pulp moisture increased the efficiency of the bench device. Fruits with higher moisture content had a mucilaginous characteristic, which resulted in the grouping of the fruits inside the bench device cylinder, hindering the pulping process.

The pulping efficiency of the experimental bench device was similar to that found in a prototype for extraction of Bixa orellana L. pulp that was developed by Math et al. (2016), which had efficiency of $92.3 \%$. A device built by Sharma, Pradhan, Naik, Bhatnagar and Singh, (2013), for pulping Aleurits fordii had efficiency of $74.6 \%$. Both studies concluded that reducing moisture of the material improves pulping efficiency.

Zanatta (2015), studied the characterization of bocaiuva pulp with manual and mechanical pulping and found efficiency of $41.4 \%$ for manual pulping, and efficiency of $30.1 \%$ for mechanical pulping (using a conventional fruit pulping device) in the best condition-fruits previously macerated in water at $95^{\circ} \mathrm{C}$ for 15 minutes.

Several studies on bocaiuva pulp extraction are found, however, few of them reported results of pulping efficiency. Thus, comparing the results of Zanatta (2015), with those found in the present study, the pulping efficiency of the experimental bench device was higher, even in the worst condition evaluated $(\mathrm{T} 1=62.5 \%)$. Moreover, pulping in the bench device does not require addition of water, which enhances yield of better quality and facilitates flour production, what it is desired. 
Contrastingly, laboratory tests showed that a trained person can manually remove $500 \mathrm{~g}$ of bocaiuva fruits in 35 minutes. The time required to reach the same amount of pulp using the bench device was 2.5 minutes, which denotes the importance of using the bench device for pulping.

In addition, the pulping of the bench device system can be stopped at any time to achieve a desired purpose. For example, production of flour needs pulp with uniform color, which requires greater control of the pulping, i.e., the process must be stopped before removing all the pulp to prevent particles of the tegument that compromise color uniformity. On the other hand, the pulp extraction can be increased for production of biodiesel, since this leads to a greater amount of pulp extracted.

Therefore, the pulping efficiency increased when the system was fed with fruits that were dehydrated for 24 hours, reducing the pulping time to 120 seconds. This was probably because the longer the dehydration time the lower the fruit moisture, since low-moisture pulp does not adhere to the device cylinder wall, making the pulping easier. The pulping efficiency of fruits that were dehydrated for 24 hours was $96.0 \%$, and the device extraction yield was 5.5 $\mathrm{kg} \mathrm{h}^{-1}$.

The fabrication cost of the experimental bench device was approximately US\$ 310 , including labor and materials, plus US\$ 166 for the electric motor. No specific devices for pulping palm fruits are found in the Brazilian market; pulping devices for other fruits, in general, cost more than US\$1,000.

In view of these findings, the bench device is an efficient, compact, low cost, and easy-to-assemble and operate device for extraction of bocaiuva fruits, which can help to increase in income of communities processing these fruits by aggregating value to their products.

\section{Conclusion}

An experimental bench device to pulp bocaiuva fruits was designed and fabricated in this study. The prototype was fabricated with low-cost materials and was compact and easy to operate. The performance evaluation, in terms of pulp extraction yield, showed higher efficiency than those reported in the literature. The highest pulping efficiency was achieved with fruits that had low moisture content.

The prototype proved to be effective for pulping bocaiuva fruits, making it possible to replace manual by mechanized pulping, since it reduced the time and increased the yield of the process. Moreover, the pulping process of the device can be controlled, thus, enabling the obtaining of high-quality pulp or increasing the pulp extraction, depending on the purpose of the process.

\section{Acknowledgements}

Transferred to the title page The authors thank the Coordination for the Improvement of Higher Education Personnel (CAPES), the Brazilian National Council for Scientific and Technological Development (CNPq), the Foundation to Support the Development of Education, Science and Technology of the State of Mato Grosso do Sul (FUNDECT) for the financial support (PAPOS n. 164/2015 FUNDECT/CAPES-Program in Biotechnology and Biodiversity - Pró Centro Oeste, Phase III).

\section{References}

Aristone, F., \& Leme, F. M. (2006). Como fazer farinha de bocaiúva: Guia completo e livro de receitas. Manual didático (1st ed.). Campo Grande-MS.

Arruda, A. S. O., Matos, F. R. N., Machado, D. ode Q., \& Arruda, C. D. B. (2015). Economia Solidária e desenvolviento local sustentável: um estudo de caso em um sistema de agricultura familiar. Organizações Rurais \& Agroindustriais, 17, 163-178.

Askeland, D. R., \& Wright, W. J. (2014). Ciência e engenharia dos materiais (3rd ed.). Norte Americana New York: Cengage Learning.

Azevedo Junior, W. C. de, Faria, A. M. de M., Santana, A. C. de, Reis, W. D. da S., \& Almeida, C. N. da S. (2018). Potencial da acrocomia aculeata no desenvolvimento endógeno da região de Cuiabá, Brasil. Revista Iberoamericana de Economía Ecológica, 28(13902776), 52-65.

Bhandari, V. (2010). Design of machine elements. Norte Americana, New York.: Tata McGraw-Hill Publishing Company Limited.

Bortolotto, I. M., Amorozo, M. C. de M., Guarim Neto, G., Oldeland, J., \& Damasceno-Junior, G. A. (2015). Knowledge and use of wild edible plants in rural communities along Paraguay River, Pantanal, Brazil. Journal of Ethnobiology and Ethnomedicine, 11(1), 46. https://doi.org/10.1186/s13002-015-0026-2

Brasil. (2007). Resolução RDC nº 20, de 22 de Março de 2007. Regulamento Técnico Sobre Disposições para 
Embalagens, Revestimentos, Utensílios, Tampas e Equipamentos Metálicos em Contato com Alimentos-Publicada no Diário Oficial da União, 26/03/2007.

Cavalcanti-Oliveira, E. D., Silva, P. R., Rosa, T. S., Moura, N. M. L., Santos, B. C. P., Carvalho, D. B., ... Freire, D. M. G. (2015). Methods to prevent acidification of Macaúba (Acrocomia aculeata) fruit pulp oil: A promising oil for producing biodiesel. Industrial Crops and Products, 77, 703-707. https://doi.org/ 10.1016/j.indcrop.2015.09.022

Ciconini, G., Favaro, S. P., Roscoe, R., Miranda, C. H. B., Tapeti, C. F., Miyahira, M. A. M., ... Naka, M. H. (2013). Biometry and oil contents of Acrocomia aculeata fruits from the Cerrados and Pantanal biomes in Mato Grosso do Sul, Brazil. Industrial Crops and Products, 45, 208-214. https://doi.org/10.1016/ j.indcrop.2012.12.008

Coimbra, M. C., \& Jorge, N. (2012). Fatty acids and bioactive compounds of the pulps and kernels of Brazilian palm species, guariroba (Syagrus oleraces), jeriv a (Syagrus romanzoffiana) and macauba (Acrocomia aculeata). Journal of the Science of Food and Agriculture, 92, 679-684. https://doi.org/10.1002/jsfa.4630

Cruz, R. P., Ferreira, F. B., \& Rodrigues, F. D. Á. (2017). Simulação e análise econômica da produção de biodiesel a partir de óleo de macaúba. The Journal of Engineering and Exact Sciences, 3(3), 533-560. https://doi.org/10.18540/2446941603032017533

Farias, T. M. (2010). Biometria e processamento dos frutos da macaúba (Acrocomia sp.) para a produção de óleos (Master's Thesis, Universidade Federal de Minas Gerais, Belo Horizonte-MG, Brazil). Retrieved from http://www.bibliotecadigital.ufmg.br/dspace/handle/1843/BUOS-8WLH8P

Garcia, A., Spim, J. A., \& Santos, C. A. (2012). Ensaio dos materiais (1st ed.). Rio de Janeiro-Brazil: Editora LTC.

Jarimopas, B., \& Ruttanadat, N. (2007). Development of a young coconut fruit trimming machine. Journal of Food Engineering, 79(3), 752-757. https://doi.org/10.1016/j.jfoodeng.2006.01.082

Kloster, S., \& Cunha, L. A. G. (2014). Desenvolvimento Territorial e Turismo Rural: As relações possíveis. Desenvolvimento Em Questão, 12(27), 66-94. https://doi.org/10.21527/2237-6453.2014.27.66-94

Kopper, A. C., Saravia, A. P., Ribani, R. H., \& Lorenzi, G. M. A. C. (2009). Utilizaçao tecnológica da farinha de bocaiuva na elaboraçao de biscoitos tipo cookie. Alimento Nutrição Araraquara, 20(3), 463-469.

Leite, J. A. (2012). Bancada multifuncional para simulação de mecanismos de falhas falhas em máquinas (Master's Thesis, Universidade Estadual Paulista, Guaratingueta-SP, Brazil). Retrieved from https://repositorio.unesp.br/handle/11449/97056

Machado, L. W., \& Rovere, E. L. La. (2017). The Traditional Technological Approach and Social Technologies in the Brazilian Semiarid Region. Sustainability, 10(1), 25. https://doi.org/10.3390/su10010025

Machado, W., Guimarães, M. F., Lira, F. F., Santos, J. V. F., Takahashi, L. S. A., Leal, A. C., \& Coelho, G. T. C. P. (2015). Evaluation of two fruit ecotypes (totai and sclerocarpa) of macaúba (Acrocomia aculeata). Industrial Crops \& Products, 63, 287-293. https://doi.org/10.1016/j.indcrop.2014.11.002

Mankins, J. C. (2009). Technology readiness assessments: A retrospective. Acta Astronautica, 65(9-10), 1216-1223. https://doi.org/10.1016/j.actaastro.2009.03.058

Martha, L. F. (2002). Um programa gráfico-interativo para ensino de comportamento de estruturas, versão educacional 2.11 para Windows. Rio de Janeiro-Brazil: Tecgraf PUC-Rio. Retrieved from https://www.tecgraf.puc-rio.br/ftool

Math, R. G., Ramesh, G., Nagender, A., \& Satyanarayana, A. (2016). Design and development of annatto (Bixa orellana L.) seed separator machine. Journal of Food Science and Technology, 53, 703-711. https://doi.org/10.1007/s13197-015-2019-5

Melconian, S. (2012). Elementos de máquinas. São Paulo, Brazil: Editora Érica.

Moreira Junior, O. (2013). Tecnologias para pequenos produtores rurais: Desidratador hibrido e MCH funcionando com BFTs. Dourados, Mato Grosso do Sul, Brazil: Editora Seriema.

Munhoz, C. L., Guimarães, R. D. C., Nozaki, V. T., Sanjinez-Argandoña, E. J., Hiane, P. A., \& Macedo, M. L. R. (2014). Preparation of a cereal bar containing bocaiuva: Physical, nutritional, microbiological and sensory evaluation. Acta Scientiarum, 36, 553-560. https://doi.org/10.4025/actascitechnol.v36i3.18561

Nascimento, A. D. P. Do, Soares, L. A. L., Stragevitch, L., \& Danielski, L. (2016). Extraction of Acrocomia 
intumescens Drude oil with supercritical carbon dioxide: Process modeling and comparison with organic solvent extractions. Journal of Supercritical Fluids, 111, 1-7. https://doi.org/10.1016/j.supflu.2016.01.013

Nunes, A. A., Favaro, S. P., Galvani, F., \& Miranda, C. H. B. (2015). Good practices of harvest and processing provide high quality Macauba pulp oil. European Journal of Lipid Science and Technology, 117, 2036-2043. https://doi.org/10.1002/ejlt.201400577

Obayopo, S. O., Taiwo, K. A., Owolarafe, O. K., \& Adio, S. A. (2014). Development of a plantain slicing device. Journal of Food Science and Technology, 51(7), 1310-1317. https://doi.org/10.1007/s13197-012-0654-7

Oliveira, D. M., Clemente, E., \& da Costa, J. M. C. (2014). Bioactive Compounds and Physicochemical Parameters of Grugru Palm (Acrocomia aculeata) from Brazil: Pulp and Powder. Food Science and Technology Research, 20(1), 7-12. https://doi.org/10.3136/fstr.20.7

Owolarafe, O. K., Adetan, D. A., Olatunde, G. A., Ajayi, A. O., \& Okoh, I. K. (2013). Development of a locust bean processing device. Journal of Food Science and Technology, 50(2), 248-256. https://doi.org/10.1007/ s13197-011-0335-y

Pennachio, H. (2017). Boletim Sociobiodiversidade (1st ed., Vol. 1). Companhia Nascional de Abastecimento, Brasilia.

Raji, A. O., \& Olofin, A. F. (2011). Design and Development of Leaf Protein Juice Extraction Machine. Journal of Industrial Research and Technology, 3(1), 69-77.

Ramos, I. M. L., Ramos Filho, M. M., Hiane, P. A., Braga Neto, A. J., \& Siqueira, M. E. de A. (2008). Qualidade nutricional da polpa de bocaiúva. Ciência e Tecnologia de Alimentos, 28(Supl.), 90-94. https://doi.org/ 10.1590/S0101-20612008000500015

Sharma, V., Pradhan, R. C., Naik, S. N., Bhatnagar, N., \& Singh, S. (2013). Evaluation of a centrifugal impaction-type decorticator for shelling tung fruits. Industrial Crops and Products, 43(1), 126-131. https://doi.org/10.1016/j.indcrop.2012.06.046

Silva, G. C. R., \& Andrade, M. H. C. (2013). Development and simulation of a new oil extraction process from fruit of macauba palm tree. Journal of Food Process Engineering, 36(1), 134-145. https://doi.org/ 10.1111/j.1745-4530. 2011.00657.x

Zanatta, S. (n.d.). Caracterização da macaúba (casca, polpa e amêndoa) e análise sensorial através da Educação do Gosto (Master's Thesis, Universidade de São Paulo, Piracicaba-SP, Brazil). Retrieved from http://www.teses.usp.br/teses/disponiveis/64/64135/tde-05052015-101840/pt-br.php

\section{Copyrights}

Copyright for this article is retained by the author(s), with first publication rights granted to the journal.

This is an open-access article distributed under the terms and conditions of the Creative Commons Attribution license (http://creativecommons.org/licenses/by/4.0/). 